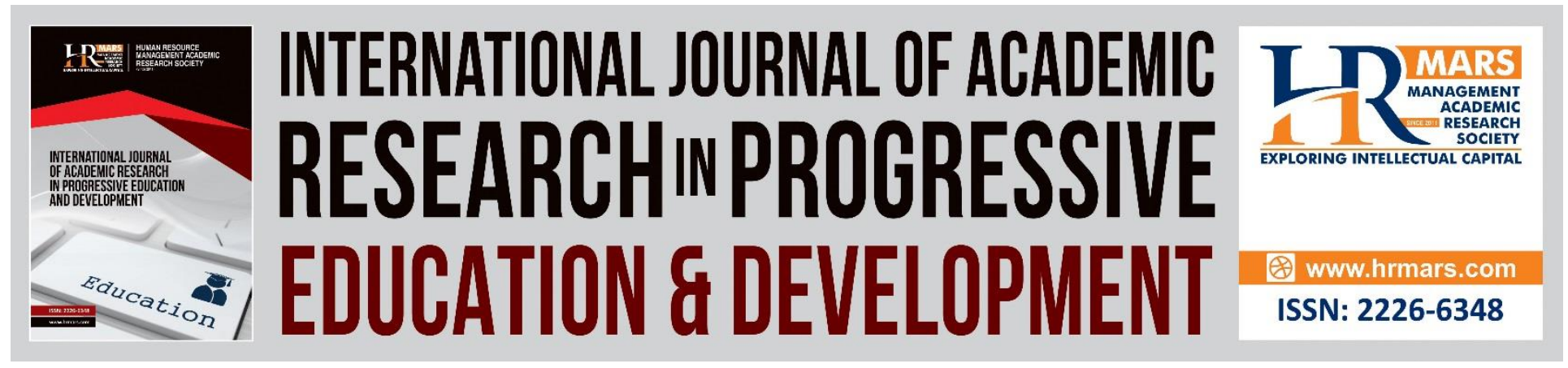

\title{
Going Back to Basics: Effectiveness of Reading English Newspaper on Vocabulary Knowledge of Malaysian Secondary Level ESL/EFL Students
}

Ambiga Thiagarajah \& Abu Bakar Razali

To Link this Article: http://dx.doi.org/10.6007/IJARPED/v10-i2/10065 DOI:10.6007/IJARPED/v10-i2/10065

Received: 10 April 2021, Revised: 13 May 2021, Accepted: 27 May 2021

Published Online: 21 June 2021

In-Text Citation: (Thiagarajah \& Razali, 2021)

To Cite this Article: Thiagarajah, A., \& Razali, A. B. (2021). Going Back to Basics: Effectiveness of Reading English Newspaper on Vocabulary Knowledge of Malaysian Secondary Level ESL/EFL Students. International Journal of Academic Research in Progressive Education and Development, 10(2), 766-781.

Copyright: (C) 2021 The Author(s)

Published by Human Resource Management Academic Research Society (www.hrmars.com)

This article is published under the Creative Commons Attribution (CC BY 4.0) license. Anyone may reproduce, distribute, translate and create derivative works of this article (for both commercial and non-commercial purposes), subject to full attribution to the original publication and authors. The full terms of this license may be seen at: $\underline{\text { http://creativecommons.org/licences/by/4.0/legalcode }}$

Vol. $10(2)$ 2021, Pg. 766 - 781

http://hrmars.com/index.php/pages/detail/IJARPED JOURNAL HOMEPAGE

Full Terms \& Conditions of access and use can be found at http://hrmars.com/index.php/pages/detail/publication-ethics 


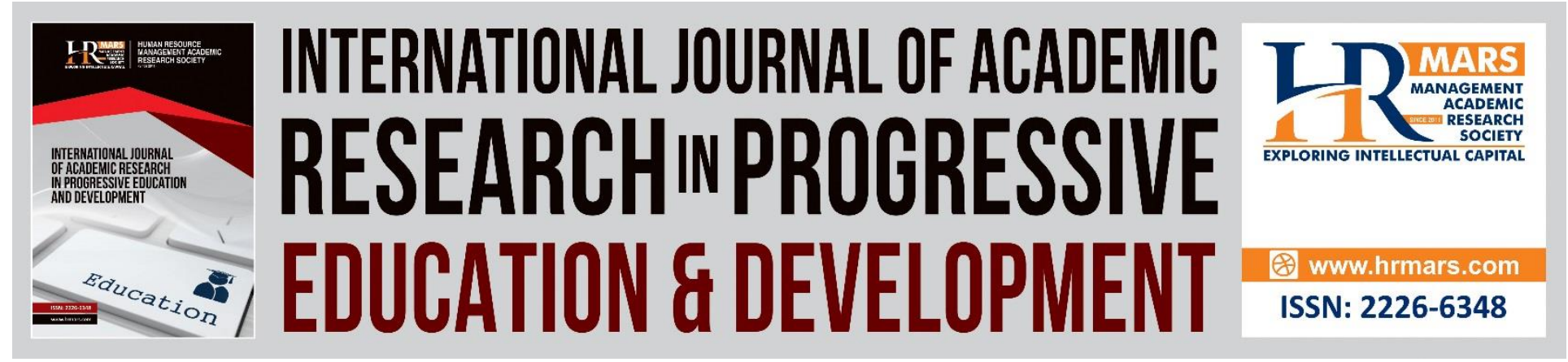

\title{
Going Back to Basics: Effectiveness of Reading English Newspaper on Vocabulary Knowledge of Malaysian Secondary Level ESL/EFL Students
}

\author{
Ambiga Thiagarajah \& Abu Bakar Razali \\ Faculty of Educational Studies, Universiti Putra Malaysia (UPM), 43400 UPM Serdang, Selangor, \\ Malaysia \\ Email: ambigartrj@gmail.com \& abmr_bakar@upm.edu.my
}

\begin{abstract}
This research investigates the effectiveness of English newspaper on vocabulary knowledge of Malaysian secondary school students in an international school in Malaysia. The researchers utilized a quasi-experimental research design with the non-equivalent control group design. As many as 69 students in Year 7 participated in this research. These participants formed the control intact group and experimental intact group in an international secondary school in an urban setting in Lembah Klang, Malaysia, and they came from the same age group and English proficiency level. The collection of data was done through the pre- and post-tests and survey questionnaire. The data were analysed using paired samples T-test and descriptive statistics. The findings of the research indicated that the use of English newspaper as part of the lesson has improved the vocabulary knowledge of the Year 7 students (mean for pre-test: 18.92; mean for post-test: 23.39 ). They also have their preferred reading genres (i.e., movie and entertainment news, sudoku and puzzles, comic, and modern gadgets technology) as well as positive perceptions to reading the newspaper. The researchers provide some suggestions for future practice and research with regards to the use of newspapers for ESL/EFL students to improve their vocabulary knowledge.
\end{abstract}

Keywords: ESL/EFL Students, Leisure Reading, Newspaper, Vocabulary Knowledge

\section{Introduction}

Vocabulary knowledge is an integral part in order for the learners to acquire and master the English language successfully. According to Manan, Ali and Sarimah (2013), comprehending an academic or non-academic text can be easy if the learners has a good vocabulary knowledge. Moreover, it is widely understood that good vocabulary knowledge is necessary in order to understand any form of text. However, in Malaysia, majority of the students possess limited or insufficient vocabulary knowledge, which impacts both their proficiency skills in reading, writing, speaking and listening (Zulkefly \& Razali, 2017). This can be seen through the learners' struggle 
Vol. 10, No. 2, 2021, E-ISSN: 2226-6348 @ 2021 HRMARS

and the difficulties that they face in utilising the language for both formal and informal language practices in the learning of English as a second language (Harji et al., 2015; Zulkefly \& Razali, 2019).

In English language, learning vocabulary items play an important role in all of the language skills, such as listening, speaking, reading, and writing (Nation, 2011). For instance, as highlighted by Nor, Mazlan and Rajab (2015), limited vocabulary knowledge is often seen as a challenge for students when they try to express their thoughts in written form. Students in Malaysia face struggles in coping with the language skills, such as reading, writing, speaking and listening due to the lack of vocabulary knowledge (Azlina \& Mei, 2015). According to Sivabalan (2013), although there are various instructional methods to teach vocabulary in the classroom, Malaysian students are still weak in their vocabulary knowledge level. She further highlights that in Malaysia, the students tend to struggle in acquiring vocabulary knowledge and they face great struggle in understanding the context of the word that they read.

In Malaysia, the government is constantly urging its citizens to make leisure reading as a habit (Mohamad Jamrus \& Razali, 2019). Reading more non-academic text is constantly highlighted in the news, and it was echoed by the former Deputy Prime Minister and Education Minister of Malaysia, Tan Sri Dato' Haji Muhyiddin in his 2009 book fair launch speech that Malaysian students should read more non-academic materials (The Star Online, 2009). More recently, the government has been placing great emphasis on leisure reading habits. It is reported by Menon (2019) that between the year 2021 and 2030, the Ministry of Education is taking measures in order to transform Malaysia into a reading nation. This step is taken in order to increase the language mastery level, especially English, among the citizens.

Thus, leisure reading is considered as one of the major aspect in language acquisition and language learning. According to Lee and Wong (2017), habitual and positive reading habits among students tend to facilitate their language learning, increase general knowledge, and develop vocabulary level. This is mainly because leisure reading improves student's general knowledge as well as help in their academic growth (Ali \& Razali, 2019), in that students gain new information, releases stress and improve their English language skills (Inderjit, 2014). Leisure reading also enhances students' general knowledge and improve their vocabulary acquisition. Indirectly, leisure reading also encourages lifelong learning habit among students (Jayavalan \& Razali, 2018).

However, the well-known reality is that in Malaysia is that students are reading books mainly for national examinations rather than to gain additional knowledge or for their own pleasure (Mustafa, 2018). As a reflection of this situation, Malaysian students lack vocabulary knowledge due to their lack of exposure to reading materials and their lack of interest in reading for pleasure (Ali \& Razali, 2019). Furthermore, Manan, Ali and Sarimah (2013) reports that the Malaysian English language syllabus does not cater with the requirements needs of the secondary school students. In addition, according to Schaar, Lapasau and Fang (2013), Malaysian individuals only read half a page a year and this falls far below the UNESCO leisure reading recommendation of 80 pages per person per year. In fact, in a study conducted by Pandian (2000) it is highlighted that $80.1 \%$ of university students are "reluctant" readers in English texts. This finding clearly shows that even at the higher level of education, students tend to read in order to fulfil only their examination and assignment needs (Lim, Razali \& Abd Samad, 2018). Therefore, to curb these 
issues, Malaysian students need to cultivate the habit of leisure at a young age, preferably during primary or secondary education so that it could enhance their vocabulary knowledge and help them to excel in their primary and secondary studies well into their tertiary studies.

To make leisure reading as a prominent aspect of the society, several aspects must be looked into. One main aspect that needs to be focused on is the type of resources that are available and whether or not it interests the students. In this regard, newspapers can be taken into consideration as an important and readily accessible material for the students to use as a leisure reading material due to its affordability and availability. Reading newspaper on daily basis can help students to improve their language skills and general knowledge (Swaminathan, 2017). The choices of words and the writing style of news articles are direct and clear, which makes it easier for the learners to comprehend (Ahmmed, 2016). The language used in newspaper is appealing because it uses simple terms. The habit of reading newspaper is vital in order to gain social awareness and to form habitual reading. Grundy (1993, as cited in Wang, 1994), highlighted that many ESL/EFL teachers are inclining towards the use of newspaper in their classrooms due to its availability and its relevance to the society and cultural issues (Jayavalan \& Razali, 2018). Reading English newspapers can help students learn vocabulary and increase their reading speed because the contents of the English newspapers are rich and emotive. Newspapers can increase the number of words that a student learns and there are various topics that appeals to the teenagers and children. Moreover, the inclusion of newspaper articles in the daily lesson provides a positive impact in both teaching and learning.

Like other Asian countries, the availability to the current forms of media, such as online news is becoming popular in Malaysia, however, in certain scenarios in Malaysia, access to these online materials can be quite scarce. Furthermore, the mere focus on only digital text and online media is somewhat limiting students from learning from authentic materials, such as newspapers (Mohamad Jamrus \& Razali, 2019). The use of newspaper is highly important due to the reason that newspapers are easily available compared to other materials, such as magazines or books and even digital texts. Therefore, this research focuses on investigating the effectiveness of using English newspapers to increase Malaysian secondary school ESL/EFL student's vocabulary knowledge. The aims of this study are to:

1) To investigate the effectiveness of English newspaper in increasing secondary school students' vocabulary knowledge.

2) To determine reading topics (i.e., music, fashion, movies, food, travel) from English newspaper that increases secondary school students' vocabulary knowledge.

3) To describe secondary school students' perceptions towards English newspaper in increasing their vocabulary knowledge.

\section{The Use of Newspapers to Increase Vocabulary Knowledge}

One of the prominent difficulties that students often face in the second language learning is developing their vocabulary knowledge. In the Malaysian education context, vocabulary teaching is known to be less important compared to the other aspects of second language learning (Mustafa, Sain \& Razak, 2012). These researchers also highlight that vocabulary learning only presents as incidental learning in the general classroom setting. This is mainly because many 
languages are used in the Malaysian education and environment context (Zulkefly \& Razali, 2017; Zulkefly \& Razali, 2019). In the multi-ethnic and multilingual society, the students typically do not use English as their medium of instruction, as they prefer to use their mother tongues. Although English serves as the second language for many students in Malaysia (Phoon \& Abdullah, 2010), majority of them do not use English as their first language. A vast number of Malaysian students only start to learn English in preschool as a secondary or sometimes other language (Zulkefly \& Razali, 2017; Zulkefly \& Razali, 2019). Due to this, Malaysian educators find it difficult to educate young students with minimal exposure to the English language. Many ESL classrooms in Malaysia face various in issues in terms of time constraints and lack of language proficiency due to the present of mother tongue or first language (Jayavalan \& Razali, 2018; Kasuma \& Tan, 2019).

The standard of English language in Malaysia has declined and this has become a serious issue to Malaysian teachers and other stakeholders in the education system (Lee \& Wong, 2017; Ali \& Razali, 2019). Furthermore, Kaur and Abdullah (2017) also revealed that with lack of English usage and minimum exposure among students, this has caused them to possess low proficiency level in the English language. According to Lewis (2000), one of the major challenges faced by language learners are increasing their vocabulary knowledge in order to improve their proficiency level (Ali \& Razali, 2019; Jamrus \& Razali, 2019). Furthermore, the English teachers in Malaysia mostly focus on other aspects of the language, such as reading and writing skills and mastery level of grammatical aspects (Musa, Lie \& Azman, 2012). In a study conducted by Rashid (2011), he found that Malaysian secondary school students face difficulties in comprehending text from their English textbook. Furthermore, the researcher highlighted in his study that the secondary school students can only comprehend basic text which contains simple vocabulary form. This directly hinders learners' in depth engagement in the classroom and prolonged task or activities due to lack of vocabulary knowledge. Therefore, there exists an immediate need for an effective method to look into this matter.

One of the most useful resources readily available for both teachers and students are newspapers (Valva, 2009). Valva highlights that newspapers can be used as a motivating medium in encouraging and stimulating students to indulge themselves in the reading activities as well as the activities organised. Therefore, printed media, such as newspapers, are an excellent teaching and learning aid for both the teachers and the students. It indirectly helps the teachers to conduct activities that incorporates information that suits the current generations' lifestyle and needs. Shen (2006) points out that the main reason for leisure reading among young adults were to obtain information and entertainment purpose. In the study, the researcher found out that magazines and newspapers are the most preferred reading materials for them. Furthermore, according to Cheyney (1982, as cited in Ahmmed, 2016), newspaper functions as a textbook that contains latest information on both local and international matters. Therefore, the students will be able to gain general knowledge as well as improve their English language usage.

It is very clear that it is vital to learn vocabulary in context and that is where newspapers appear particularly suitable (Shoari \& Aidinlou, 2015). Reading English newspapers aids students to develop vocabulary and learn to read a passage in a fast manner and comprehend the key concepts that are presented in the given text (Ahmmed, 2016). The use of newspaper as an additional resource material in teaching and learning of English has increasing in recent years (Pandey, 2019). Newspaper have the power to develop the English language skills (Wolswinkel, 
2008). In a study conducted by Afzal and Harun (2013), the researchers point out that the English lesson can be fun when the teachers and students discuss about the daily news published in the newspapers. They also reported that by exploring the news articles, students can learn on how the writer express their thoughts and how they manipulate the word knowledge.

\section{Research Methodology}

This study seeks to find out the effectiveness of reading English newspaper increases secondary school students' vocabulary knowledge. In this regard, this study employed the quasi experimental research which includes the pre-test and post- test method as well as the implementation of treatment (i.e., the use and exposure to newspapers to the research participants) to enhance their vocabulary knowledge. The research was conducted in a private school in Kelana Jaya, Selangor, Malaysia. In this quasi experimental study, two classes of 69 Year 7 (or Grade 7) ESL/EFL students, aged 13 years old, were selected by the researchers. These classes were identified as the control and experimental group respectively and a pre-test were given to both the classes. Next, the intervention was introduced and conducted with the experimental group. The intervention took place for 3 weeks based on the length of the treatment and availability of class time. Meanwhile, the control group was taught or exposed using the traditional method of teaching. Towards the end of the study, a post-test was given to both groups in order to identify any changes in the experimental group after the intervention.

The quasi-experimental quantitative research design was employed because the data collection method was conducted under the normal school conditions (Subon, 2016), in which the students were assigned to their respective set teaching classes (i.e., intact groups). In regards to the current context of the research setting where this study was conducted, it is important to note that for each classroom, the students are already separated into two levels based on their Year 6 checkpoint (Equivalent to UPSR in the government school) results in the primary school. In addition, for the new students, a placement test (Year 6 Cambridge progression paper) will be administered in order to determine their English proficiency level prior to admission to the school. The pre-test and post-test design can be summarised as per the Table 1 below:

Table 1. Non- Equivalent Pre-Test and Post Test Research Design

\begin{tabular}{|l|l|lr|l|}
\hline $\begin{array}{l}\text { Experimental } \\
\text { Group }\end{array}$ & $\mathrm{O}_{1}$ & $\begin{array}{l}\mathrm{X} \text { (Cambridge Checkpoint English } \\
\text { textbook/module with the use of newspaper) }\end{array}$ & $\mathrm{O}_{3}$ \\
\hline $\begin{array}{l}\text { Control } \\
\text { Group }\end{array}$ & $\mathrm{O}_{2}$ & $\begin{array}{l}\text { Cambridge Checkpoint English } \\
\text { textbook/module only }\end{array}$ & 1 & $\mathrm{O}_{4}$ \\
\hline
\end{tabular}

The $\mathrm{O}_{1}$ and $\mathrm{O}_{2}$ represents the pre-test observations, $\mathrm{X}$ indicates the intervention for the experimental group and $\mathrm{O}_{3}$ and $\mathrm{O}_{4}$ indicates the post-test observations for the experimental and control group respectively. Prior to the intervention for the experimental group, both control and experiment groups were given a common test which were administered by their respective subject teachers. This test measured the students' vocabulary level before conducting the experiments. Next, the control group was taught using the Cambridge Checkpoint English 1 textbook and the experimental group was taught using both the Cambridge Checkpoint English 1 textbook and also through the exposure to and use of newspaper articles while learning English 
vocabulary. Here the researchers carried out activities that incorporated the use of newspapers. After the completion of the intervention, the participants were given the post-test that measured the influence of the use of the treatment (i.e., newspaper) on their vocabulary knowledge.

The control group and the experimental intact groups were using this textbook mainly because it is recommended by the Cambridge and the school's Scheme of Work for English includes the usage of this textbook as the primary source for both teaching and learning. In addition to the use of textbook, the researchers used newspaper articles as an additional resource to teach the vocabulary aspects. This serves as an intervention for the experimental group. In regards to the treatment which was given to the experimental intact group, in addition to the use of the Cambridge Checkpoint 1 textbook / module, the researchers also selected several reading articles from The Star newspaper that were used with the experimental intact group.

In this study, a survey questionnaire was utilised in order to identify the students' preferences towards the topics in the newspaper and to analyse students' perception towards leisure reading using newspaper. This questionnaire was administered to the experimental group students after the completion of the intervention. This is mainly because after the activities and lessons during the intervention period, the students would have a better understanding on their preferences towards the newspaper topics. The questionnaire used in this present research is adapted from one previous study, to which Sections B and C are adapted from Lee and Wong (2017). The researchers selected these two previous research mainly because the questions in these two questionnaires are related to the present study as well a newspaper topics and their perception towards using the newspaper as a reading material.

The questionnaire consists of 20 Likert scale items to be responded. The questionnaire consists of three sections. Section A in the questionnaire consists of the basic demographic information of students such as their name, age, gender and the schooling year/level. For section B, the Likert scale options of, "very important", "important", "neutral", "low importance" and "not important" were given. On the other hand, for section C, the Likert scale options of, "strongly agree", "agree", "neutral", "disagree", "strongly disagree" were given. Section B focuses on the features of newspaper where the students rate the relevance of the reading topics based on their individual preference. Section C focuses on students' interest in reading newspaper and their perception in choosing newspaper as part of their leisure reading session. Both section $B$ and $C$ consists of ten items each. In order to identify the frequency of use for each item, a five point Likert scale was used in the questionnaire.

The raw data from the pre-test and the post-test were recorded and tabulated using the Statistical Package for Social Science (SPSS) version 21. The total score for both the control and experimental group were computed for each participant. This step was done for the control as well as the experimental group. Inferential Statistics, i.e., the Paired Samples T-Test was employed in this study mainly because this research involves repeated measures of related samples. This version of T-Test was used in order to identify and compare the means value between the pre and the post tests. Meanwhile, the data collected from the post intervention questionnaire were also coded and calculated. The raw data were tabulated and analysed using descriptive analysis. A Descriptive analysis was used to determine the mean and the standard deviation to determine the students' preferences in reading topics and their perception towards 
the use of newspaper in leisure reading (Galti, 2018). This quantitative analysis would determine the students' preference towards the newspaper topics and their perception towards leisure reading, particularly the use of newspaper in increasing their vocabulary knowledge after the intervention, which are the research questions (2) and (3).

\section{Results and Findings \\ Effectiveness of Newspaper in Improving ESL/EFL Students' Vocabulary Knowledge}

The paired t-test was conducted to analyse the level of the student's vocabulary level after being given the treatment and comparing the results between the control and experimental groups. This comparison was done by comparing the vocabulary score for both groups in their pre and post-test. Based on the Table 2 below, it clearly indicates that after the intervention, students using both Cambridge Checkpoint English 1 textbook and through the exposure to use of newspaper articles had higher test score than the control group (students using the Cambridge Checkpoint English 1 textbook only), this is because, for the experimental group, the mean (M) value for pre-test is 18.92, and upon the completion of the post test, the mean value increased to 23.39. The significant differences indicate the use of English newspaper does improve students' vocabulary knowledge.

Table 2. Results of paired T-test for the differences of the pre-test and post-test for the experimental and control group.

\begin{tabular}{|l|ll|ll|l|l|l|}
\hline \multirow{2}{*}{ Score } & \multicolumn{2}{|l|}{ Pre-test $(n=33)$} & \multicolumn{2}{l|}{ Post-test $(n=36)$} & T-test & Sig. 2-tailed \\
\cline { 2 - 7 } & $\mathrm{M}$ & SD & $\mathrm{M}$ & SD & $\mathrm{t}$ & $p$ \\
\hline Control & 19.88 & 2.90 & 21.48 & 3.94 & -3.710 & 0.001 \\
Experimental & 18.92 & 3.16 & 23.39 & 3.41 & -13.978 & $<0.000$ \\
& & & & & & \\
F-stat & & & & & 3.023 & 0.087 \\
\hline
\end{tabular}

Based on Table 2 above, the test for homogeneity of variance provides an F-statistic and a significance value ( $p$-value). If the probability value is greater than 0.05 ( $p$-value $>0.05)$ the group of variances treated as equal. However, if $p$-value $<0.05$ the variances are unequal and had violated the assumption of homogeneity of variance. Based on the result of Levene's Test for Equality of Variances, when the null hypothesis is failed to be rejected, then there is no difference in the variances between the two groups. In this study, the researchers found that there is a difference in the variances between the two groups, where the $p$ value for control group is 0.001 and experimental group is $<0.000$. This clearly means that there is a significant difference between the control and experimental groups' vocabulary test scores. Therefore, the use of English newspaper in the classroom does help the students to improve and increase their vocabulary knowledge. This is mainly because through the activities conducted in the class and by reading the news articles, students managed to acquire new words which they can use in their writing and daily conversation. That said, the researchers conclude that the use of English newspaper as an intervention method helps the experimental group students' to improve their vocabulary knowledge. 
INTERNATIONAL JOURNAL OF ACADEMIC RESEARCH IN PROGRESSIVE EDUCATION AND DEVELOPMENT

Vol. 10, No. 2, 2021, E-ISSN: 2226-6348 @ 2021 HRMARS

\section{Reading topics that increase ESL/EFL students' vocabulary knowledge}

Table 3. Newspaper topics based on their importance.

\begin{tabular}{|l|l|l|}
\hline Topics & Mean & Std. Deviation \\
\hline Political News & 1.6944 & 0.98036 \\
Regional / Locational News & 1.9167 & 0.87423 \\
Sports News & 2.6944 & 1.84885 \\
International News & 2.3889 & 1.22539 \\
Business Corporation News & 1.1111 & 0.39841 \\
Movie and Entertainment News & $\mathbf{4 . 8 6 1 1}$ & $\mathbf{0 . 3 5 0 7 4}$ \\
Sudoku and Puzzles & $\mathbf{4 . 4 1 6 7}$ & $\mathbf{0 . 7 3 1 9 3}$ \\
Comic & $\mathbf{4 . 6 6 6 7}$ & $\mathbf{0 . 5 3 4 5 2}$ \\
Modern Gadgets Technology & $\mathbf{5 . 0 0 0 0}$ & $\mathbf{0 . 0 0 0 0 0}$ \\
Health and Nutrition & 4.2778 & 0.74108 \\
\hline
\end{tabular}

Table 3 above focuses on the types of newspaper articles where the students rate the relevance of the reading topics based on their individual preferences. Out of 10 preferences given, the mean value of 5.00 indicate that students have given much importance to the "modern gadget and technology" when it comes to newspaper reading topic. Being in youthful age group and surrounded by the modern technology era, "modern gadget and technology" will be the most favourite topic, with mean(M) value of 5.00 followed by movie and entertainment, (mean= 4.86 ), comic, (mean =4.67) and Sudoku and puzzles, (mean =4.42). As for other topics, the researchers believe that these other topics may not be of students' interest. For example, students may not focus on business and corporate related issue at this age group mainly because it does not relate to their lifestyles and needs. This can be concluded that the students' age group plays a significant role when it comes to selecting the reading topics. Another strong point to highlight here is, the standard deviation value for all categories are lower than mean value. A low standard deviation indicates that the values tend to be close to the mean of the set. This indicates that there is less variation when the variable tested for further action.

ESL/EFL students' perception towards English newspaper in increasing their vocabulary knowledge

Table 4. Students' perceptions in reading newspaper

\begin{tabular}{|l|l|l|}
\hline Personal Experiences & Mean & SD \\
\hline Hobby & 2.3611 & 1.09942 \\
\hline Study & 3.1667 & 1.32017 \\
\hline Other Activity & $\mathbf{3 . 3 8 8 9}$ & $\mathbf{1 . 2 7 1 1 7}$ \\
\hline Boring & 2.5833 & 1.05221 \\
\hline Learn More & $\mathbf{3 . 5 2 7 8}$ & $\mathbf{0 . 8 1 0 1 5}$ \\
\hline Pastime & $\mathbf{3 . 8 0 5 6}$ & $\mathbf{0 . 5 2 4 7 8}$ \\
\hline Recommended by my teacher & $\mathbf{4 . 4 1 6 7}$ & $\mathbf{0 . 5 0 0 0 0}$ \\
\hline School Library & 3.2500 & 1.10518 \\
\hline
\end{tabular}


Table 4 above reveals student's personal perceptions in reading The Star newspaper. Based on the perceptions shared by secondary school students, school teachers play a major role to cultivate newspaper reading habit among the school children (mean $=4.4167$ ). This means that the school teacher plays a big role in imparting a positive perception on the use of newspaper in the English lesson or in learning English. Next, the students also preferred to read newspaper as their pastime (mean= 3.80). This is mainly because the newspapers are easily available for them and the content (i.e. gadgets and technology) in it are appealing to their age group. Another aspect is, the students also read the newspaper to learn more (mean=3.52) and for other activities such as Sudoku and puzzle (mean =3.38). This clearly indicates that when the newspapers are easily available it and doesn't required much effort in getting it, the students tend to read them (Wolswinkel, 2008). Moreover, being in the 12 years old age group, they have a limited time with their own gadgets and technology mainly due to parental supervision and school rules and regulations. Thus, students tend to read newspaper more when they are in school especially under teacher's guidance.

The researchers also believe that newspaper articles are one of the more accessible teaching resources and an additional source will help student's vocabulary level and in same time will increase the reading habit among them. These resources will assist the students to learn on the how to use the words according to the appropriate context and with the grammatical features.

\section{Discussion and Conclusion}

Through the inclusion of the English newspapers in the classroom, it has been proven that the students in the experimental group improved significantly in their vocabulary knowledge. This can be clearly seen through the post-test scores, to which the paired test that was conducted in order to compare both the pre-test and post-test for both groups showed that the use of English newspapers had a positive effect on the students' vocabulary level with the mean difference of 1.60 for the control group and 4.47 for the experimental group. The exposure to the English newspaper has given these students an alternative way to learn and understand the new words in the newspaper articles. After the intervention, there is evidence of students' improvement in their vocabulary post-test, (mean=23.39) which indicates that the use of English newspaper has helped the students' to learn new words through the scaffolding method. The improvement in the mean, from 18.92 to 23.39 for the experimental group also indicates that the use of English newspaper has a significant impact on their vocabulary level.

Moreover, students' interest also plays a main part in using newspaper as part of the lesson. In this study, the mean value of 5.00 clearly indicates that the students highly prefer to read "modern gadget and technology" of the newspaper during the intervention period. Due to their age group, the students want to read more about the latest gadget in order for them to share this information with their peers. This is followed by "movie and entertainment news", "Sudoku and puzzles" and "Comic" sections. All these topics and sections contains news are related to their current 21st century environment and their interests. Thus, in order to make the inclusion of newspaper in the classroom more practical, the type of news articles needs to be considered based on the students' age groups and interests. 
Next, the students' perception also indicates that the teacher plays a significant role in encouraging them to read the newspapers. With the mean value of 4.41 , the school teachers need to include engaging lessons that requires the students to read newspaper. Furthermore, at the age of twelve, the students tend to read newspaper in their pastime as well as to learn more. This indicates that Year 7 is a suitable level for teachers to encourage students to read newspaper by including this material in their lesson. As highlighted by Wolswinkel (2008), reading newspaper will become habitual if students were exposed to newspaper as a reading material since young. Thus, the researcher believes that all these factors need to be consider in facilitating the use of English newspaper in the classroom.

In this regard, the use of English newspaper in the classroom can also a platform for students to acquire vocabulary knowledge especially with close guidance from the teacher. This is because, towards the end of the intervention period, the students tend to interact more with their peers in order to complete the task compared to the beginning of the intervention period. Here, through Vygotsky's notion of scaffolding, the teacher also guides the students to become more engaged in the task by collaborating with their peers. Compared to the use of the textbook, where the students tend to depend on the teacher to provide the answer or solution, newspapers tend to provide the students an opportunity to learn themselves with minimal guidance from the teacher. Moreover, the content of the newspaper is appealing to their age group with the inclusion of latest trend and news. This makes it easier for the students to connect with the information in the newspaper compared to the textbook. This study shares the perspectives on Olson and Prath (2000) who highlighted that the use of English newspaper in the classroom helps students to extend abilities that will make them self-coordinated and self-managed students. This is mainly because, the teacher managed to incorporate the topic that interest the students based on their age group by providing the guidance in the initial stage of the intervention for the students to read the newspapers as part of their lesson and also encouraged them to read them outside of the classroom setting.

In summary, based on the research findings, the researchers believe that it is vital to implement various types of teaching resources and not just focus mainly on the use of textbooks or workbooks or even on only digital and online resources. In vocabulary teaching and learning, the nature of teaching resources plays a vital part. Educators should utilize viable resources and materials for instructing vocabulary (Shoari \& Aidinlou, 2015; Mohamad Jamrus \& Razali, 2019). As such, the researchers recommend a few suggestions on how best to use English newspapers to develop ESL students English language vocabulary, as well as a number of suggestions on future research endeavours.

\section{Recommendations}

\section{Recommendations for Future Practice}

Vocabulary knowledge is a crucial part in the mastery of English language (Maskor \& Baharuddin, 2016). Therefore, this huge responsibility of teaching vocabulary and ensuring the students understand it lies on the shoulders of the teachers. Therefore, the teachers need to be on easily accessible materials that they can incorporate in their classroom. Based on the results of the study, it is found that English newspapers can increase and improve students' vocabulary knowledge. The researchers strongly believe that the English language teachers can utilize the 
English newspapers in their teaching process in order to create an interesting and effective vocabulary lesson (Noordin, Abd Samad, Razali, Ismail, \& Rashid, 2019). The researchers also believe that the use of English newspaper should be considered by the educators and policy makers. While it is very attractive for students and teachers to be moving towards the use of technology in the classroom (Mohamad Jamrus \& Razali, 2019), it is important to note forsake the use of readily accessible use of newspapers within and outside of the English classroom. In order to create an engaging classroom without much disturbance, students need to be taught using an effective and different method that triggers their interest as well (Lim, Razali, \& Abd Samad, 2018; Ali \& Razali, 2019).

The subscription to the daily printed newspapers tend to be affordable and more schools need to invest in this useful material. This investment is vital mainly because the newspaper contains useful information that appeals to the students as well as engage them in vocabulary learning. Furthermore, investing on printed newspaper is also fruitful mainly because other subjects can be taught using newspaper. Teachers can subscribe to the daily newspaper via their school or institution in order to make it available for students on daily basis. It can be additional resource for students to find information and to read during the lesson. The constant availability of the newspaper during the lesson will trigger the students' interest to read them.

More significantly, the results and findings of this research managed to shed light on the use of English newspaper and its usage in teaching the vocabulary to students. The use of English newspaper need to be made part of the English language lessons and the secondary school syllabus in order for teachers and students to be involved in an engaging vocabulary lesson. Given the nature of Malaysian education system and the usage of textbook in classrooms, the newspaper can be made part of the lesson that compliments the syllabus in the textbooks. Teachers can plan their lessons around the latest and current news in order to create an interest among students.

\section{Recommendations for Future Research}

Due to the benefits and positive impacts of newspapers, more studies and research needs to be carried out in order to implement this teaching resource for other learning levels and subjects. More in depth research needs to be carried out in order to understand the students' perceptions regarding the newspaper and their interest in reading them. Furthermore, since the method of research for this study is quantitative design, perhaps a qualitative research design or a mixed method approach could be used in future studies in order to get more in depth results. Moreover, this particular research only focuses on the secondary school students. Therefore, future studies should focus on other levels, such as kindergarten and primary level as well as tertiary level. Future research should include diverse age group students and various schools in order to expand the study scale and to retrieve more concrete results that can be generalized nationwide.

\section{Limitations of the Study}

This particular research mainly focuses on the aspect of using newspapers (as an act of leisure reading) in increasing the secondary school students' vocabulary knowledge. Thus, it does not touch the other reading materials that can help to improve students' vocabulary knowledge 
or the depth of their vocabulary knowledge. Furthermore, the participants are limited to secondary school students in a Malaysian school setting. Therefore, this research does not cover the primary education level or other levels of education in terms or improving the knowledge of vocabulary level. Apart from time constraint, the number of participants for the study could not be larger as only the Year 7 students were used as participants due to their English proficiency level. In order to control the threats to the validity, it is highly suggested in educational research that researchers should have the same teacher to teach all the research groups involved in the study (Creswell, 2013). However, this is usually beyond the researcher's control and it is affected by factors such as scheduling and administrative decisions in a school setting (Tan, 2016). Therefore, two English language instructors were involved. In order to make sure that the integrity of the study was preserved, the two English language instructors were well-informed and well-trained of the procedures and protocols in the study, especially in collecting the data and making sure the study is conducted in an ethical manner. The findings from this relatively small sample from one school in in one state in Malaysia might therefore not be reflective of the vocabulary level of students elsewhere. However, this study is still significant, as a first exploration, which is hoped, will lead to other similar studies on a more extensive scale.

\section{Acknowledgement}

This research was made possible due to research grant in the scheme of Geran Putra (or Putra Grant) by Research Management Centre, Universiti Putra Malaysia (UPM).

\section{References}

Afzal, N., \& Harun, M. (2013). On opinion and persuasive writing: Teaching English through editorials. The Modern Language Journal, 4(2), 57-65. DOI: https://doi.org/10.7575/aiac.alls.v.4n.2p.57

Ahmad, S., \& Rawian, M. R. (2021). Using Lexical Profiling Tools to Enhance Lexical Richness. Asian EFL Journal, 28 (2), 24-47. DOI:

Ahmmed, R. (2016). Effectiveness of reading English newspapers for improving vocabulary and reading skills of students of Dhaka University. The Millennium University Journal, 1(1), 6876. Retrieved from https://www.researchgate.net/publication/327891038_Effectiveness_of_Reading_Engli sh_Newspapers_for_Improving_Vocabulary_and_Reading_Skills_of_Students_of_Dhaka _University

Ali, A. M., \& Razali, A. B. (2019). A review of studies on cognitive and metacognitive reading strategies in teaching reading comprehension for ESL/EFL learners. English Language Teaching, 12(6), 1-18. DOI: https://doi.org/10.5539/elt.v12n6p

Asgari, A., \& Mustapha, G. (2012). Vocabulary learning strategies of Malaysian ESL students. Pertanika Journal of Social Science and Humanities, 20, (3), 751-763. Retrieved from http://www.pertanika2.upm.edu.my/Pertanika\%20PAPERS/JSSH\%20Vol.\%2020\%20(3)\% 20Sep.\%202012/13\%20pg\%20751-764.pdf

Azlina, A., \& Mei, L. L. (2015). Effect of multimedia principle on vocabulary learning among second language learners. Paper presented at the Second International Conference on Education, Social Sciences and Humanities, Istanbul, Turkey. Retrieved from 
INTERNATIONAL JOURNAL OF ACADEMIC RESEARCH IN PROGRESSIVE EDUCATION AND

DEVELOPMENT

Vol. 10, No. 2, 2021, E-ISSN: 2226-6348 @ 2021 HRMARS

https://pdfs.semanticscholar.org/07e0/ec6681317a1cb0db2c3e8db94f3522ba288f.pdf

Badiozaman, I. F. (2015). It's only words. The Borneo Post. Retrieved from https://www.theborneopost.com/2015/04/29/its-only-words/

Galti, A. M. (2018). Students' perception of learning vocabulary in Suggestopedia class. 1. ALMUQADDIMAH, A Journal of the Humanities, Law, Social \& Management Sciences, 1 (2), 1-7. Retrieved from

https://www.researchgate.net/publication/328091903_Students'_Perception_of_Learn ing_Vocabulary_in_Suggestopedia_Class

Harji, M. B., Balakrishnan, K., Bhar, S. K., \& Letchumanan, K. (2015). Vocabulary levels and size of Malaysian undergraduates. English Language Teaching, 8 (9), 119-130. Retrieved from https://files.eric.ed.gov/fulltext/EJ689121.pdf

Inderjit, S. (2014). Reading trends and improving reading skills amongstudents in Malaysia. International Journal of Research in Social Sciences, 3(5), 70-81.Retrieved from www.ijsk.org/uploads/3/1/1/7/3117743/6_reading_skills.pdf

Jayavalan, K., \& Razali, A. B. (2018). Effectiveness of Online Grammar Checker to Improve Secondary Students' English Narrative Essay Writing. International Research Journal of Education and Sciences (IRJES), 2(1), 1-6. eISSN 2550-2158 URL: http://www.masree.info/wp-content/uploads/2018/05/IRJES-VOL-2-ISSUE-1-ARTICLE1.pdf

Kasuma, S. A. A., \& Tan, D. A. I. (2019). ESL reading activities on Facebook among Malaysian university students. Pertanika Social Science and Humanities, 27(1), 101-122.Retrieved from https://pdfs.semanticscholar.org/490e/621871bbd7a0c4d1b9cb3ce2c221fe924202.pdf

Kaur, N., \& Abdullah, M. K. K. (2007). Autonomy in ESL: To what extent? Paper presented at Literary Conference (LITCON) 2007, Penang, Malaysia. Retrieved from http://journalarticle.ukm.my/6047/1/2227-4405-1-SM.pdf

Lee, J., \& Wong, S. C. A. (2017). The relationship between leisure reading habits, vocabulary and writing of English language learners (ELLs). Language Education in Asia, 8(2), 157-175. doi: 10.5746/LEiA/17/V8/I2/A03/Vun_Chu.

Lim, X. Y., Razali, A. B., \& Abd Samad, A. (2018). Self-Directed Learning Readiness (SDLR) among Foundation Students from High and Low Proficiency Levels to Learn English Language. Malaysian Journal of Learning and Instruction, 15(2), 55-81. URL: http://mjli.uum.edu.my/images/vol.15no.2/55-81.pdf

Manan, A. B., Ali N. A., \& Sarimah, S. (2013). Does the Malaysian English language syllabus cater to the academic vocabulary needs of secondary school students entering universities?Jurnal Teknologi, 65(2), 7-14. doi: http://dx.doi.org/10.11113/jt.v65.2345

Maskor, Z. M., \& Baharudin, H. (2016). Receptive Vocabulary Knowledge or Productive Vocabulary Knowledge in Writing Skill, Which One Important? International Journal of Academic Research in Business and Social Sciences, 6(11), 261-27.

McLeod, S. (2019). What is the Zone of proximal development? Retrieved from https://www.simplypsychology.org/Zone-of-Proximal-Development.html

Menon, S. (2019). Malaysians still not reading enough. The Star Online. Retrieved from https://www.thestar.com.my/education/news/ 
Jamrus, M. H., \& Razali, A. B. (2019). Augmented Reality in Teaching and Learning English Reading: Realities, Possibilities, and Limitations. International Journal of Academic Research in Progressive Education and Development, 8(4), 724-737. http://dx.doi.org/10.6007/IJARPED/v8-i4/6696

Zaki, M. I., Hassan, F., \& Razali, M. A. B. (2008). ESL students' online and offline reading strategies: Scrolling, clicking, flipping and reading. Asian Journal of University Education, 4(2), 61-78. ISSN: 1823-7797 URL: http://education.uitm.edu.my/ajue/?page_id=20

Musa, N. C., Lie, K. Y., \& Azman, H. (2012). Exploring English language learning and teaching in Malaysia .Gema online ${ }^{\mathrm{TM}}$ Journal of Language Studies, 12(1), 35-50.Retrieved from http://ejournal.ukm.my/gema/article/view/20/14

Mustafa, H. R., Sain, N., \& Abdul Razak, N. Z. (2012). Using Internet for Learning Vocabulary among Second Language Learners in a Suburban School. The 8th International Language for Specific Purposes (LSP) Seminar - Aligning Theoretical Knowledge with Professional Practice.

Mustafa, Z. (2018). Boosting the reading habit. New Straits Times. Retrieved from https://www.nst.com.my/education/2018/07/394232/boosting-reading-habit

Nor, F. M., Mazlan, M. H., \& Rajab, A. (2015). English language teachers' perceived difficulty of English skills faced by ESL learners. Akademia Baru, Penerbit, 1(1), 12-18. Retrieved from https://www.researchgate.net/publication/330716902_English_Language_Teachers'_P erceived_Difficulty_of_English_Skills_Faced_by_ESL_Learners/citations

Noordin, N., Samad, A. A., Razali, A. B. M., Ismail, L., Rashid, M. R. (2019). Theory to Practice: What Teacher Trainees Did Not Expect from Their Practicum Experience. International Journal of Language, Literacy and Translation 2(2), 42-53. DOI: https://doi.org/10.36777/ijollt2019.2.2.026

Olson, J., \& Prath, T. (2000). The instructional cycle: Teaching children and adolescents with special needs. New Jersey, NJ: Prentice Hall.

Pandey, S. K. (2019). The trend of reading newspaper among the youth in $21^{\text {st }}$ century (A study based on youth and daily Hindi newspapers of Varanasi. International Journal of Advance and Innovative Research, 1-13. DOI: https://doi.org/10.1598/rrq.39.2.2

Pandian, A. (2000). A study on readership behaviour among multi-ethnic, multi-lingual Malaysian students. Paper presented at the Seventh International Literacy and Education Research Network (LERN) Conference on Learning, RMIT University, Melbourne, Australia. Retrieved from http://.ultibase.rmit.edu.au/Articles/aug01/pandian1.htm.

Phoon, H. S., \& Abdullah, A. C. (2014). Oral vocabulary as a predictor of English language proficiency among Malaysian Chinese preschool children. The Southeast Asian Journal of English Language Studies, 20(1), 143- 156. DOI: http://dx.doi.org/10.17576/3L-20142001-11

Rashid, R. A. (2011). Vocabulary learning among less proficient young adults using children's stories. MEXTESOL Journal, 35(1), 1-11. Retrieved from https://www.researchgate.net/publication/288667489_Vocabulary_Learning_among_L ess_Proficient_Young_Adults_Using_Children's_Stories

Schaar, T., Lapasau, M., \& Fang, N. C. (2013). Reading habits of Malaysian students beyond classrooms. Studies on Foreign Languages and Cultures, 2, 114-138. Retrieved from 
INTERNATIONAL JOURNAL OF ACADEMIC RESEARCH IN PROGRESSIVE EDUCATION AND

DEVELOPMENT

Vol. 10, No. 2, 2021, E-ISSN: 2226-6348 @ 2021 HRMARS

https://www.academia.edu/people/search?utf8=\%E2\%9C\%93\&q=Reading+Habits+of+M alaysian+Students+beyond+Classrooms\%28TSchaar\%2C+Merry+Lapasau+and+Ng+Chwe e+Fang\%292013

Shoari, E., \& Aidinlou, N., A. (2015). Zone of proximal development: The effect of verbal scaffolding on improving Iranian young EFL learners' vocabulary learning. Journal of Applied Linguistics and Language Research, 2(8), 208-217. Retrieved from www.jallr.com

Sivabalan, K. (2013). Influence of using songs and dictionary in teaching vocabulary (Master dissertation, Universiti Teknologi Malaysia, Johor, Malaysia.) Retrieved from http://www.fp.utm.my/epusatsumber/pdffail/ptkghdfwP2/Kasturi\%20AP\%20Sivabalan. TP.pdf

Subon, F. (2016). Direct vocabulary instruction: The effects of contextualized word families on learners' vocabulary acquisition. Procedia - Social and Behavioral Science, 224, 284-29. doi: 10.1016/j.sbspro.2016.05.461Swaminathan, K.S.M (2017). Newspaper reading habits among the students of Arts Colleges in Madurai, Tamilnadu: A study. Indian Journal of Information Sources and Services, 7(1), 36-39. Retrieved from https://www.researchgate.net/publication/320244860_News_Paper_Reading_Habits_a mong_the_students_of_Arts_Colleges_in_Madurai_Tamilnadu_A_study

Tan, D. A. L. (2016). Investigating guided extensive reading and vocabulary knowledge performance among remedial ESL learners in a public university in Malaysia (Doctoral dissertation, University Sains Malaysia, Penang, Malaysia). Retrieved from https://core.ac.uk/download/pdf/78388981.pdf

Valva, L. (2009). Benefits of using newspaper, magazines and books in classroom. LCPJ Publishing, 2(2), 12-17. Retrieved from https://www.Icpj.pro/skedaret/1354544987Article\%2011.pdf

Wang, B. Q. (1994). Newspapers by Peter Grundy. Oxford: Oxford University Press, 1993. Issues in Applied Linguistics, 5(1), 168-171. Retrieved from https://escholarship.org/uc/item/6ph8j2qp

Wolswinkel, H. (2008). New paper reading: The explaining factors of newspapereading behavior of young adults (Master thesis, University of Twente, Enschede, Netherlands). Retrieved from https://essay.utwente.nl/59108/1/scriptie_H_Wolswinkel.pdf

Zulkefly, F., \& Razali, A. B. (2019). Malaysian Rural Secondary School Students' Attitudes towards Learning English as a Second Language. International Journal of Instruction, 12(1), 1141 1156. DOI: https://doi.org/10.29333/iji.2019.12173a

Zulkefly, F., \& Razali, A. B. (2017). Attitudes towards learning English as a Second Language (ESL): the case of students in a rural secondary school in Malaysia. Journal of Studies in Social Sciences and Humanities, 3(1), 12-34. ISSN: 2413-9270 URL:

http://www.jssshonline.com/wp-content/uploads/2016/02/JSSSH_Vol.3_No.1_2017March_12-34_Sr-No.-2.pdf 